\title{
Emilia in Othello: the problem of the unfilmic character
}

Lois Potter

\section{(2) OpenEdition}

1 Journals

\section{Electronic version}

URL: http://journals.openedition.org/shakespeare/273

DOI: 10.4000/shakespeare.273

ISSN: 2271-6424

\section{Publisher}

Société Française Shakespeare

\section{Printed version}

Date of publication: 1 November 1998

Number of pages: 149-157

ISBN: 2-84269-230-6

\section{Electronic reference}

Lois Potter, "Emilia in Othello: the problem of the unfilmic character ", Actes des congrès de la Société

française Shakespeare [Online], 16 | 1998, Online since 01 November 2007, connection on 02 May 2019. URL : http://journals.openedition.org/shakespeare/273 ; DOI : 10.4000/shakespeare. 273 


\section{S H A K E S P E A R E \\ \& $\quad$ L E $\quad$ C I N É M A}

Société Française Shakespeare

Actes du Congrès de 1998

米 $*$ *

Textes réunis et présentés par

Patricia DORVAL

publiés sous la direction de

Jean-Marie MAGUIN 
Site web : <http : //alor.univ-montp3.fr/serinf/SFS/> Liste de diffusion : <sfs-1@smrl.univ-montp3.fr >

Tous droits de traduction, de reproduction et d'adaptation réservés pour tous les pays.

(C) 1998. Société Française Shakespeare,

École Normale Supérieure, 45 rue d'Ulm. 75005 Paris.

ISBN 2-84269-230-6 


\section{EMILIA IN OTHELLO: THE PR OBLEM OF THE U NFIL M I C C H A R A C T E R}

The turning-point of Othello is Emilia's picking up of Desdemona's handkerchicf and her decision to keep it for a while rather than returning it instantly. Coming about halfway through the play, it is also the moment at which Emilia first becomes a character, after having seemed to be only a role (the heroine's servant or confidante). Yet, curiously, most of the films based on Othello either omit this episode or make drastic changes in it. Though most accounts of these films naturally concentrate on the roles of the three central characters, an examination of the «handkerchief scene» seems to me useful for two reasons. On the one hand, a chronological study of successive versions shows the increasing emphasis in performance on a view of the play as the tragedy of $t w o$ marriages rather than one, a view which naturally makes Emilia a more important character than earlier productions used to think. On the other, the various attempts to film the scene also show the problems that occur when a character is inherently unfilmic. The first of these points has already received a good deal of attention; in this essay, I shall concentrate on the second.

Emilia is vital to the plot, as the character who gives the handkerchief to Iago and later reveals what she has done. But she is also that cinematic anomaly, a character who is heard but not seen. Her entrances are so unspectacular that it is often hard to remember whether she is onstage or not. She comes into existence as a casual remark in Act I when Othello tells Iago, «let thy wife attend on her [Desdemona]» (1.3.296). On her first appearance in II.I she is given her role in the play: she is a mouth. Cassio kisses her, 
with a flippant apology to lago, and the latter replies :

Sir, would she give you so much of her lips

As of her tongue she oft bestows on me

You would have enough.

(II.1.100-2)

The rest of the scene seems to confirm Desdemona's (apparently sympathetic) reply, «Alas! she has no speech» (102), since Emilia speaks only eighteen words in all. As her part grows in the course of the play, it becomes apparent that lago's constant depiction of her as overly talkative is a tactic designed to keep her from speaking, or from being believed when she does speak. And yet he is also right: when she finally does speak in the later scenes, it tends to be at excessive length, to the point where she risks losing her audience's attention. In IV.2, with both Iago and Desdemona present, she comes close to revealing the truth without meaning to - but only Iago realizes the danger to him in what she is saying; Desdemona appears not to be listening. In the final scene the question of whether she will speak becomes a major issue first for Othello and then for Iago. The duality of her role in the play expresses itself as she alternately insists that she will speak, then asks the «gentlemen» to «let me have leave to speak» (V.2.195), then says that she will speak in despite of any who "cry shame against me» (V.2.222). She dies «speaking as I think» (V.2.251), whereas her husband, notoriously, ends his part by refusing to speak any more. Still, she is not allowed a death scene : indeed, as Kent Cartwright points out, the other characters decide that she is dead even while she is still able to speak; when they rush out in pursuit of Iago, «we are left suddenly to watch Emilia die alone, unremarked» ${ }^{2}$.

What, then, becomes of this almost invisible character in front of the camera? There have been, in all, seven commercially distributed Othello films since the end of the silent film era, beginning with the very influential one by Orson Welles (1952) ${ }^{3}$. Three are based on stage productions : Stuart Burge's film of the John Dexter production for the National Theatre, with Laurence Olivier as Othello (1965) ; Janet Suzman's film of her production with John Kani at the Market Theatre, Johannesburg (1988); and Trevor Nunn's video of his Royal Shakespeare Theatre production at the Other Place (1990). One was made for television: Jonathan Miller's B BC production (1981). The other two, like Welles's, were conceived from the start as films: the Russian version by Sergei Yutkevich (1955) and Oliver Parker's 1995 Othello.

A brief survey of these interpretations confirms what one might expect about the relation of word-based to visual-based views of Emilia. The three 
most cinematic versions of the play - those of Welles, Yutkevich, and Parker - cut all of her lines prior to the scene in which she tells Iago about the handkerchief, and only Yutkevich even shows her picking it up (she puts it in her bosom, smiles, but says nothing). In this respect they are following, probably without knowing it, the practice of the threc surviving silent films of the play (two made in Italy, one in Germany), none of which allows Emilia any real agency in stealing the handkerchief. In the 1908 Pathé film Iago steals it himself; in the 1914 Ambrosio version, she picks it up but Iago snatches it from her almost at once. This business recalls that of the 1887 Verdi opera, which, like most stage performances of the play at that period, makes Emilia a very minor role - and in fact the opera is often as important an influence as the play on early films made outside the AngloAmerican culture. In Dmitri Buchowetsky's 1922 version, Iago orders Emilia to steal the handkerchief while they are both on board the ship bound for Cyprus, giving her a jewel as a reward; however, he later makes this episode irrelevant by stealing the handkerchief himself. These soubrettish young Emilias say virtually nothing even in the captions ; their existence is largely gestural and the development of their relationship with Iago is unimportant.

It is when technology makes it possible to give Emilia a voice that the handkerchief soliloquy becomes a problem for film-makers. But why should it be a "problem» at all ? To understand the filmic perspective on this scene, one need only watch what happens at this point in the two most faithful renderings : Burge's film of the 1964 National Theatre production and Jonathan Miller's version for the BBC in 1981, with Joyce Redman and Rosemary Leach respectively as Emilia. Their blocking is remarkably similar. The screen delineates a space - the theatre set in one case, a room in the other. Both women remain upstage of Othello and Desdemona, look after them as they go out, then make a long diagonal movement (Redman darting, Leach at a more leisurely pace) to what is clearly recognized as downstage center, where they pick up the handkerchief and soliloquize about it. The result might almost be the hypothetical scene described by the television director in David Hare's Amy's View, when he is explaining why he thinks the theatre is dead :

You know, you go to the theatre. A character comes in the door. You think, oh my God! He's going to cross the room. Jump-cut, for Christ's sake, just jump-cut! And then next thing - oh, Christ, you just know it! The bastard is going to sit down and talk. ${ }^{4}$

Hare's character is something of a straw man in the play, but at this point he is absolutely right about the differences between the two art forms. 
«Making an entrance», one of the great skills of an actor, is largely a waste of time in film; the same is true of talk which cannot be illustrated. Strictly speaking, Emilia does not enter at this point - she has presumably come on with Desdemona at III.3.278 - but since she has no lines and the scene between Othello and Desdemona is an intimate one, the director will generally keep her in the background or even bring her on as they go out. This inevitably means a long crossing of the stage in order to reach the handkerchief. The speech which follows allows for movement on stage - for instance, Emilia can start to follow Desdemona, then hesitate as she remembers lago's interest in the handkerchief - but in film the direction she takes cannot be so clearly specified : without a longshot that would reduce her to a tiny puppet, it would be hard to suggest, as the theatre can do through movement, that she is being pulled back and forth between the respective claims of Desdemona and Iago. Soliloquy itself is not unfilmic, at least not since both stage and cinema broke away from their reluctance to acknowledge the audience, but direct address to the camera remains a privilege granted only to important characters ; used frequently for lago's numerous soliloquies, it is apparently considered inappropriate for a minor figure like Emilia.

Burge was filming a stage production, so he probably had no choice about the long entrance. The fact that Jonathan Miller was directing for television makes his staging more surprising, although, given the constraints on television filming and its set-bound nature, it is likely that he too had very little choice at this point. In her ingenious account of the BBC production, Lynda Boose suggests that Miller conceived of the Cyprus interiors as masculine spaces which the women always feel uncomfortable at entering ${ }^{5}$. Certainly, the awkwardly long entrance gives the viewers time to adjust to Emilia's presence, of which they had probably not been conscious during the previous scene. It also gives Emilia a long time in which to recognize what she is looking at, pick it up, and think about what she is going to do with it. Insofar as it depends on closeup, the scene is eminently cinematic. But its effect depends entirely on the actress, not the camera. Rosemary Leach plays the speech as she might have done it on the stage, though perhaps with less movement : our interest is in the tone in which she says «my wayward husband» and in her rueful smile as she thinks of Iago. Perhaps, given the delicacy of this study of the gradations of self-deception and evasion of responsibility, it would be wrong to complain about the sense of dead space at its beginning and the general lack of cinematically interesting camera choices. The purpose of the BBC productions was to focus on the words of the text and the performances of the actors, and in this respect this scene, at least, works admirably. 
On the other hand, both Suzman and Nunn, though they too were filming stage productions, deliberately avoided the long entrance. Suzman shows Emilia lurking in the shadows as Othello and Desdemona go out, then cuts to a closeup of her hand on the handkerchief, as if she has pounced on it. Her soliloquy is the startlingly passionate outburst of someone who is being given her first chance to speak freely. Smelling the handkerchief like a starving woman, she refers to «my wayward husband» with bitterness which makes it clear that "wayward» is a euphemism for something more like «abusive». A bit of directorial rewriting makes her final decision more consciously guilty. Whereas a number of earlier Emilias (including Joyce Redman at the National Theatre) had altered «I'll have the work ta'en out» (III.3.296) to some version of «I'll have a copy made», thus ensuring that the audience does not suspect her of actual theft, Dorothy Gould was made to say simply that she would «give it to lago».

Nunn does not show the picking up of the handkerchief at all; assuming that most viewers already know the story, he tantalizes them instead with the possibility that things could have gone completely differently. Desdemona announces dinner time to Othello by firmly slamming a gold watch on the table in front of him. After leaving with Othello, she dashes back, obviously in search of something she had forgotten, then, with great relief, picks up... not the handkerchief, but the watch, and rushes off again. The interval follows, and the second half opens, perhaps, some hours later. Emilia, apparently the only character not attending evening chapel (a hymn is being badly played offstage) lies in an easy chair puffing on a pipe. She sees the handkerchief on the other side of the stage and crosses to it languidly. Both her smoking and her whistling (in the earlier scene of the arrival at Cyprus) mark her as a Chekhovian figure, rather like Masha in The Seagull or that other Masha in The Three Sisters - both of them unhappily married women. And indeed this treatment is in keeping with Nunn's heavily subtextual, «Chekhovian» approach to the play, which was underlined by its late nincteenth-century costumes. Paradoxically, though it provided far more detail than any other production, it kept Emilia's motivation opaque - one of the factors that made Zoe Wanamaker's performance so consistently interesting.

Whatever they choose to do about Emilia's finding/stealing of the handkerchief, films of Othello obviously must show her giving it to her husband if the rest of the plot is to make any sense. In most versions, Iago obtains the handkerchief by flirting with her, and most Emilias show a mixture of pleasure and unease when, having got what he wants, he dismisses her. The exception is Welles's treatment of this scene. Having directed the fifty-year-old Michael MacLiammoir to imagine lago as impotent, he cast as Emilia an actress (Fay Compton) even older; moreover, her role before this 
scene had been so heavily cut that, as one British critic complained when the film was first released, a spectator unfamiliar with the play would not know that she was lago's wife ${ }^{6}$. The scene in which he forces her to give him the handkerchief is played with a great sense of tension, but much of its effect comes from the fact that the actors share the attention with the spiral staircase on which they are standing, part of the fantastic Piranesi-like background which film critics have identified with the Iago universe. Its shape suggests that Emilia is being drawn into a web, or vortex, of deception (at the end of the film the shadows of the prison-like bars on the window will fall on her as well as on Othello). On the other hand, Yutkevich places this episode in an outdoor setting, which eliminates the idea of entrances: Emilia makes Iago chase her among the pillars of a ruined temple, and the goat wandering in the background provides a silent comment on their motives.

One reason for the obliqueness of the Welles and Yutkevich interpretations was the puritanism of the 1950s, when they were made. Virtually all subsequent versions, needless to say, have made the sexual content of the scene much more explicit, even though nearly all have followed Welles in hinting that Iago is impotent. Even when the treatment of the handkerchief scene is relatively light, therefore, there is a subtext of unhappy marriage. Thus, Joyce Redman plays Emilia as a loving wife to Frank Finlay's cold lago, who lets her kiss him as a reward for her services but snaps at her to leave him almost immediately afterwards. The relationship is more ambiguous in Miller's BBC version. Iago appears in the doorway behind Emilia, a potentially sinister effect, but at first he remains at a safe distance, with a table and numerous props between them. His jocular rudeness makes her decide, on impülse, to tell him about the handkerchief; "What will you give me» is only a way of speaking, equivalent to "Won't you be pleased when you know...». The conversation is genial and, though by the end Emilia begins to have some doubts about what she has done, an apparently affectionate push from him is enough to make her leave in good humour. Suzman's interpretation is at the other extreme. Iago does not enter; he is suddenly there, as one can be in a film. The fact that Emilia feels his presence without needing to turn, and that the camera shows him only from the waist down, holding a knife, emphasizes the sinisterly sexual aspect of his power over her. A sickly yellow light plays over the scene, quite different from the airy lightness that accompanies the laughter and gameplaying of the BBC version. At the end of the scene, Iago tosses the handkerchief in the air and catches it ; here, a camera trick allows it to float for a moment, a trifle «light as air». In Oliver Parker's film, «I have a thing for you» is the first line spoken by Emilia (Anna Patrick), and she addresses it to Iago as she crawls into his (clearly not her) bed. What she wants him to give her is obvious. With no need for subtextual suggestion, the scene spares 
us nothing of his sexual cruelty toward her.

David Hare's television director, just before making the comment quoted above, insists that «The image has taken the place of the word». Curiously, the one image which would lend itself most easily to the film is rarely used by it: I mean the handkerchief, so closely associated with Emilia's role in the play. Stage productions have always made the most of this important prop: in the nineteenth century, it was traditional for Cassio to bind his wound with it, so that Othello could point to it when he asked, too late, "How came you, Cassio, by that handkerchief / That was my wive's ?» $(V .2 .319-20)^{3}$. I recently saw a production where Iago took it from the wounded Cassio in V.1 and handed it to Othello, who later used it to strangle Desdemona ${ }^{8}$. The fact that it cannot be seen in detail does not matter in such cases, although most spectators must wonder how Othello himself can identify it in the scene (IV.1) where he is supposed to see it in Cassio's hand; hence, it is common theatrical practice for Iago to get hold of it and wave it at Othello at close range. Yet everyone who reads the play must wonder about the appearance of the «handkerchief / Spotted with strawberries» (III.3.434-5), with embroidery so beautiful that both Emilia and Cassio want to make copies of it. It would be easy enough, in a film, to satisfy our curiosity by showing the object in a close up, thereby solving the problem of finding a cinematically interesting substitute for Emilia. Perhaps the handkerchief is best seen as the metaphorical equivalent for Desdemona, object of desire and the gaze, the character on whom the camera, like the other characters, most frequently and lovingly dwells ${ }^{9}$. No conceivable actress could ever completely fill the symbolic role required of Desdemona by the other characters; the never-quite-visible handkerchief, however, floats before us as a series of available symbols of the mysteriously idealized and suspected woman : its lightness, its artifice, its loveliness, and the fact that it can easily be passed from hand to hand. As if by instinct, the cinema, like the stage, chooses to leave its beauty to the imagination. In Emilia's relationship to this strange object, as to Desdemona, lies her reason for existence. We look at her only when she is looking at them.

Lois POTTER 


\section{N O T E S}

${ }^{1}$ This paper, originally illustrated with video extracts, has been completcly rewritten for this volume. The film versions mentioned or discussed in it are (I give date of release, name of director, studio, and current availability):

1909 Gerolamo Lo Savio. Filme d'Arte Italia/Pathé (not commercially available).

1914 Arrigo Frusta: Ambrosio (not commercially available).

1922 Dmitri Buchowetski : Wörner (film ; available on video).

1952 Orson Welles: Mercury/Mogador (film; available on video).

1955 Sergei Yutkevich: Mosfilm (film).

1965 Stuart Burge: British Home Entertainment (film; available on video).

1981 Jonathan Miller : BBC (video).

1988 Janet Surman : Othello Productions / Focus Films / Portobello Productions (available on video).

1990 Trevor Nunn: Primetime (video).

1995 Oliver Parker : Castle Rock (film ; available on video).

${ }^{2}$ Kent Cartwright, "Audience Response and the Denouement of Othello», in Othello: New Perspectives, ed. Virginia Mason Vaughan \& Kent Cartwright. Rutherford, Madison and Teaneck, Fairleigh Dickenson University Press ; London and Toronto, Associated University Presses, 1991, p. 166-7.

${ }^{3}$ One might also add the Othello of Bard Productions (1985), available on video from The Media Group. I shall not discuss it here because 1) it is not known in Europe and 2) the performance of the actress playing Emilia is of interest only insofar as it shows how much the play as a whole can suffer if this part is not well cast.

${ }^{4}$ David Hare, Amy's View, London, Faber and Faber, 1997, p. 52.

5 Lynda E. Boose, «Grossly Gaping Viewers and Jonathan Miller's Othello». Shakespeare, the Movie, ed. Lynda E. Boose \& Richard Burt, London, Roulledge, p. 190.

${ }_{7}^{6}$ Paul Dehn, News Chronicle, 24 February 1956.

${ }^{7}$ This business is recorded in promptbooks for Edmund Kean, J. P. Kemble, W. C. Macready, and Edwin Booth (Folger Shakespeare Library microfilms, $n^{\circ} 3$, 16, 17, 19). Another acting edition of the play, supposedly based on J.P. Kemble's version, has a printed stage direction for Cassio to take the handkerchief from his pocket when Othello asks him about it (Folger $n^{\circ} 20$ ).

${ }^{8}$ At the National Theatre, Prague, dir. Ivan Rajmont, in January 1998.

${ }^{9}$ For more on the voyeuristic aspects of Othello films, especially Welles's, see Virginia Vaughan, Othello: a Contextual History, Cambridge University Press, 1994, p. 104-6. She draws, of course, on Laura Mulvey's influential essay, "Visual Pleasure and Narrative Cinema», first published in The Screen, 1975, then reprinted in Laura Mulvey, Visual and Other Pleasures, Bloomington and Indianapolis, Indiana University Press, 1989; see especially p. 25. Mulvey 
modifies her views in other essays in this volume, notably the 1983 essay, «Changes: Thoughts on Myth, Narrative and Historical Experience», p. 15976. 